\title{
Hürthle Cell Adenoma in a Hashimoto's Thyroiditis Patient: A Rare Case Report
}

\author{
Ramesh Mahadev Tambat ${ }^{1}$, Sreenivas MD , Tejas AP', Nitin Kumar K ${ }^{1}$, Sadiq Nawaz F ${ }^{1}$, Guneet Singh ${ }^{1}$, \\ Yogendra Shrestha ${ }^{2 *}$, Jeet Bahadur Moktan ${ }^{2}$
}

${ }^{1}$ Department of General Surgery, Sapthagiri Institute of Medical Sciences and Research Institute, India

${ }^{2}$ Department of Pharmacy Practice, Sri Adichunchanagiri College of Pharmacy, Adichunchanagiri University, India

*Corresponding author: Shrestha Y, Research Scholar, Department of Pharmacy Practice, Sri Adichunchanagiri College of Pharmacy, Adichunchanagiri University, BG Nagara-571448, Karnataka, India, Tel: +917348944358; E-mail: dryogendrastha@gmail.com

Received: September 09, 2021; Accepted: September 20, 2021; Published: September 27, 2021

\begin{abstract}
Hürthle cell adenoma is a rare variant of benign lesion of thyroid gland, however aggressive nature and potential controversies about its malignant nature still remains. Pre-operative diagnosis is difficult, fine needle aspiration cytology may show Hürthle cell lesions, but final diagnosis is confirmed by histopathology for capsular and vascular invasion. Here in we report a case of a 32-year-old female who presented with a swelling in front of the neck of one-year duration. The total thyroidectomy with functional block dissection was performed and histopathology revealed Hürthle cell adenoma -Thyroid mass Hashimoto's thyroiditis - adjacent thyroid lymph node's - reactive changes.
\end{abstract}

Keywords: Hürthle cell adenoma; Hashimoto's thyroiditis

\section{Introduction}

Thyroid Hürthle cell tumors are rare neoplasms which account for less than 5\% of all thyroid tumors. These tumors have been associated with various of benign thyroid disorders, including Hashimoto's thyroiditis, hyperthyroidism, nodular goitre, and thyroid neoplasms, where they are thought to be oncocytic metaplasia [1]. As of the most recent WHO classification, these are a form of tumour that arises from thyroid follicles [2]. Recent research into the molecular landscape of Hürthle cell carcinoma has revealed that it is distinct from other differentiated thyroid malignancies, indicating that it is not a subtype of follicular

Citation: Tambat RM, Sreenivas MD, Tejas AP, et al. Hürthle Cell Adenoma in a Hashimoto's Thyroiditis Patient: A Rare Case Report. Clin Case Rep Open Access. 2021;4(3):194.

(C)2021 Yumed Text. 
www.yumedtext.com | September-2021 | ISSN: 2582-5038 | https://dx.doi.org/10.46527/2582-5038.194

carcinoma thyroid, as previously thought $[3,4]$. Women are likely to develop Hürthle cell carcinoma. Its female-to-male ratio ranges from 1.6 to $4.8: 1$ [5].

Ultrasound preoperative diagnosis is difficult. Hürthle cell cancer appears as hypoechoic to hyperechoic lesions on ultrasonography, and no preoperative feature can differentiate Hürthle cell carcinoma from adenoma [5,6]. The intraoperative

frozen section and fine needle aspiration cytology [FNAC] cannot reliably differentiate cancer from adenoma [7]. For management and a better prognosis for the patient, a detailed assessment for capsular and vascular invasion is required. Surgical management, which includes whole or near-total thyroidectomy, has been the most common treatment choice. USC>3, tumor size $>4 \mathrm{~cm}$, and thyroglobulin $>500 \mathrm{ng} / \mathrm{dl}$ with negative anti-thyroglobulin antibody have been reported as surgical criteria for Hürthle cell tumors [8]. Radioactive iodine therapy may result in a survival benefit only for those who do not have a residual disease, whereas postoperative chemotherapy or external beam radiation do not provide a survival benefit [9].

Because of its rarity, this case is being described in order to gain a deeper understanding of Hürthle cell carcinoma diagnosis and management.

\section{Case Report}

A 32-year-old woman presented with a one-year-long swelling in the front of her neck. The swelling developed gradually and measured $2.5 \mathrm{~cm} \times 1.5 \mathrm{~cm}$ in size, with no discernible progression. There were complaints of throat pain, although pain during swallowing and trouble swallowing were denied. growth, on the other hand, were denied. There was no history of thyroid cancer in the family or previous exposure to radiation. A solitary swelling was seen in front of the neck on physical examination, which moves with swallowing. Which covered approximately $2 \mathrm{~cm}$ inferiorly from the sternal notch, $3 \mathrm{~cm}$ superiorly from the chin, and laterally to the anterior border of the sternocleidomastoid muscle. The surface seemed to be smooth. There are no dilated veins, scars, or sinuses to be found. There was no localized temperature rise or tenderness on palpation, and the size was confirmed to be around $2.5 \mathrm{~cm} \times 1.5 \mathrm{~cm}$, with well-defined and smooth boundaries and a soft to firm consistency. The carotid arteries have been felt. There is no palpable lymph node hypertrophy.

Preoperative findings showed slight increase in Thyroid stimulating hormone (TSH)-5.11 uIU/mL, whereas T3-2.20 nmol/mL and T4-121 nmol/mL and preoperative serum calcium $9.2 \mathrm{mg} / \mathrm{dl}$. All routine investigations, complete hemogram, urine routine, liver and kidney profile, serology, blood sugar levels were unremarkable. Immunology showed Antithyroid Peroxidase antibody -37.2 IU/mL, Antithyroglobulin Antibody -7.7 which was suggestive of autoimmune disorder related to thyroid.

An ultrasonography of the neck was done and revealed that both thyroid lobes were enlarged, with a background of course reflectivity, indicating thyroiditis. The isthmus seems to have a $1.9 \mathrm{~cm} \times 1.1 \mathrm{~cm} \times 2.5 \mathrm{~cm}$ hypoechoic lesion that extends into the left lobe of the thyroid. There were cystic components in the lesion, as well as peripheral vascularity but no interior vascularity or microcalcifications. Three prominent hypoechoic lymph nodes measuring up to $8 \mathrm{~cm} \times 6 \mathrm{~cm}$ and demonstrating hilar vascularity are found near the lower pole of the thyroid and at level IV. Fine needle aspiration shown smears are cellular, show follicular epithelial cells in sheets and clusters admixed with lymphocytes. The epithelial cells shown Hürthle cell changes with large round nuclei and fine chromatin with many cells showing nucleoli. Moderate eosinophilic cytoplasm. Scant thick colloid and infiltrate of lymphocytes was seen with lymphoid follicles and Hürthle cell neoplasm was ruled out. 
Total thyroidectomy with functional block dissection of left and central neck was performed. Right thyroid lobe measuring 5 $\mathrm{cm} \times 2.5 \mathrm{~cm} \times 2 \mathrm{~cm}$ and single grey bits of tissue measuring $2 \mathrm{~cm} \times 1.5 \mathrm{~cm} \times 1 \mathrm{~cm}$ and left neck lymph node $4 \mathrm{~cm} \times 4 \mathrm{~cm} \times 2$ $\mathrm{cm}$ was removed. Post-surgery, thyroid profile shown T3-2.20 nmol/L, T4- $121 \mathrm{nmol} / \mathrm{L}, \mathrm{TSH}-5.11$ [HIGH], and serum calcium $-7.7 \mathrm{mg} / \mathrm{dL}$ (FIG. $1 \& 2$ ).

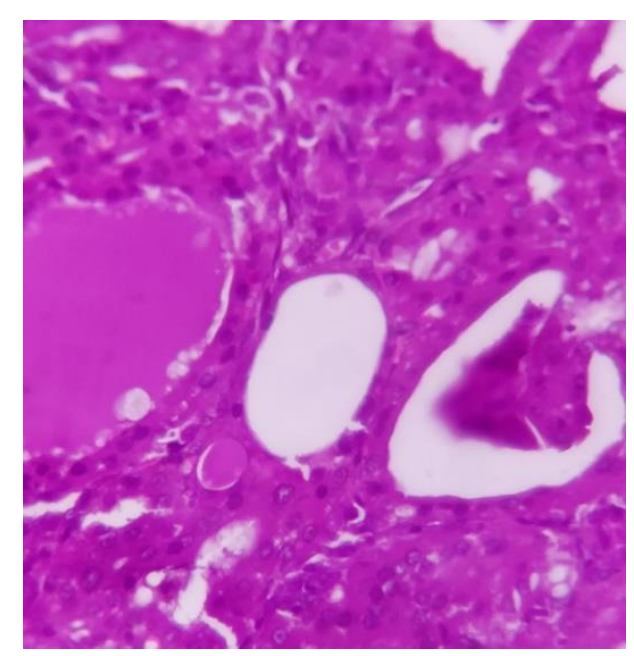

FIG. 1. Oncocytic cell displaying round nucelli with prominent and abundant eosinophilic granular cytoplasm.

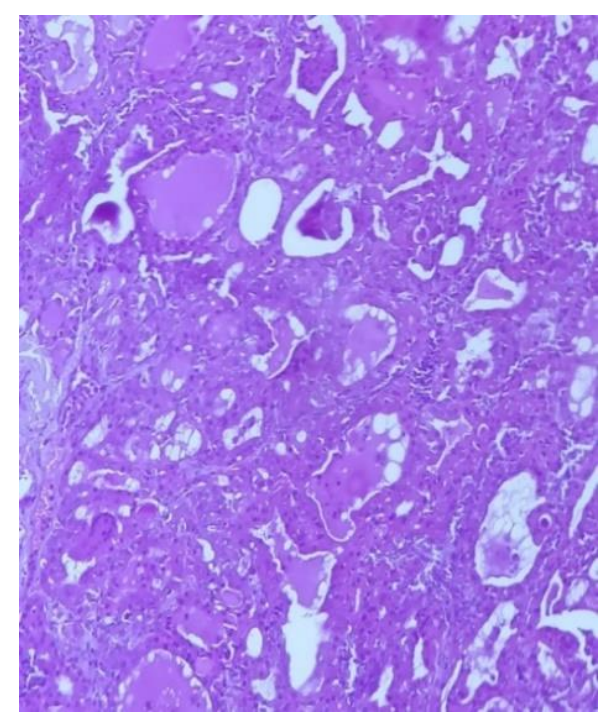

FIG. 2. Diffuse tumor cells, rich in mitochondria.

Histopathology revealed encapsulated tumor composed of small round to oval cells with abundant eosinophilic granular cytoplasm arranged in follicular and papillary pattern, in areas the cells show mild nuclear atypia and presence of nuclear grooves, multinucleated osteoclastic giant cells were noted, the invasion tumor is $2 \mathrm{~mm}$ from nearest surgical margin and the adjacent thyroid tissue shows features of Hashimoto's thyroiditis.

Sectional study of operative lymph nodes on table dissected from level $3^{\text {rd }}, 4^{\text {th }}, 5^{\text {th }}$ and $6^{\text {th }}$ compartment of neck shows reactive lymphadenitis, no evidence of tumor deposits. No evidence of nuclear overcrowding optically clear nuclei tumor necrosis, capsular and vascular invasion. 
The patient reported dry mouth and throat, as well as severe pain at the surgical site, in the post-operative period. The patient was discharged and put on post-operative follow up treatment on Thyroxine $75 \mathrm{mcg}$ once daily, calcium $500 \mathrm{mg}$ and vitamin $\mathrm{D}_{3} 250 \mathrm{IU}$ thrice daily for 2 days and calcitriol $0.5 \mathrm{mcg}$ once for 2 days. And planned for periodic thyroid function evaluation and thyroglobulin examination to rule out recurrence. After a month of post-operation reassessment revealed TSH-19.106 mIU/ML (FIG. 3-6).

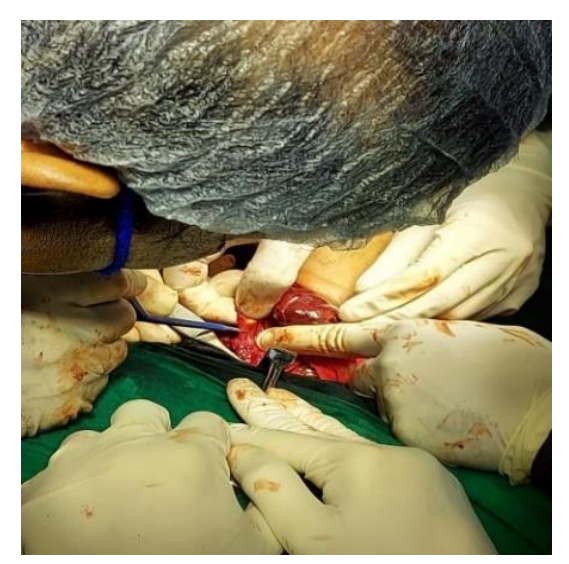

FIG. 3. Superior thyroid pedicle identification.

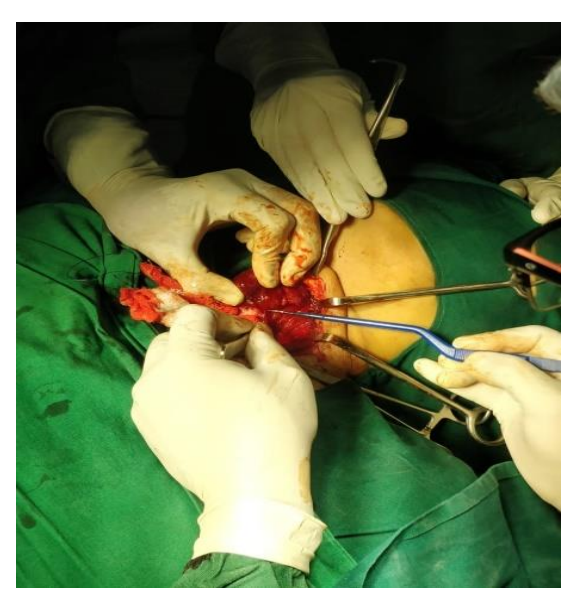

FIG. 4. Mobilization of right lobe of thyroid.

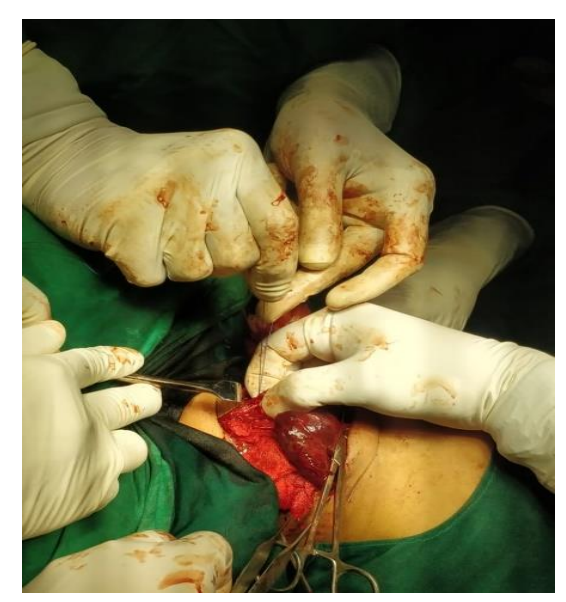

FIG. 5. Ligation of Inferior pedicle of thyroid. 


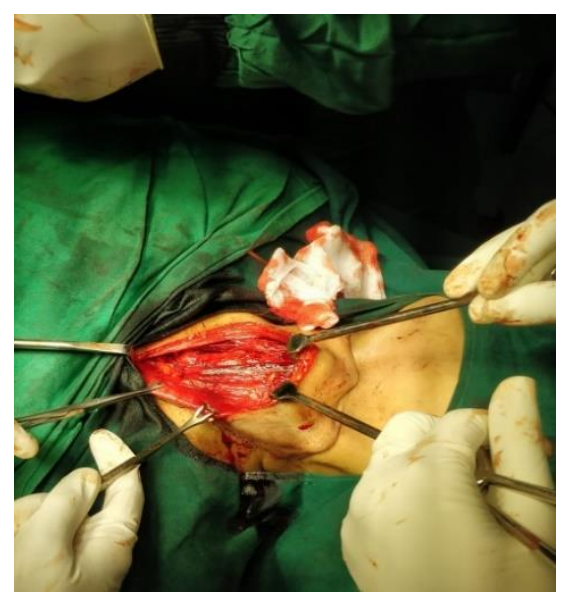

FIG. 6. Post total thyroidectomy.

\section{Discussion}

Hürthle cell carcinoma has a more aggressive clinical course than any other differentiated thyroid carcinoma, with particular drawbacks such as a greater rate of regional lymph node metastases, recurrences, and cause-specific fatality [10].

Fine needle aspiration cytology revealed Hürthle cell alterations in our patient, and Ultrasonography revealed a hypoechoic lymph node in the level IV left side. The patient underwent total thyroidectomy and functional lymph node dissection on left side, histopathology revealed Hürthle cell adenoma with no deposits in lymph node.

Hürthle cell alterations can be detected by fine needle aspiration cytology, however distinguishing between adenoma and carcinoma before surgery is tough $[11,12]$. Genetic tests may aid in early detection and distinction of adenoma from neoplasia. Aneuploidy, H-ras mutation, and allelic variation in mitochondrial DNA are some of the genetic abnormalities identified in Hürthle cell cancer where the cellular profile index [ Ki67] was shown to be greater, suggesting that it could be used as an early diagnostic marker, as per Donatini G, et al. [13].

Total thyroidectomy with left functional lymph node dissection, level IV, measuring $4 \mathrm{~cm} \times 4 \mathrm{~cm} \times 2 \mathrm{~cm}$, was performed in this case and same was suggested by Stojadinovic, et al. [14]. However, Kushchayeva Y, et al. found tumors less than $2 \mathrm{~cm}$ in size that were locally invasive or may even had distant metastases [15]. Neck lymphadenectomy is recommended for clinically/radiological/biopsy proven adenopathy. Three to four months after surgery, a radio-iodine scan should be performed to check for residual thyroid tissue; if residuals are identified, I-131 ablation with $100 \mathrm{mCi}$ should be considered, followed by a total body scan [16].

Post-operative thyroxin $75 \mathrm{mg}$ once daily was given, and routine thyroid function monitoring, periodic assessment of thyroglobulin antibodies and thyroglobulin followed by $\mathrm{I}^{131}$ whole body scintigraphy and chest $\mathrm{x}$ ray for follow-ups and evaluation of possibility of recurrence.18FDG-PET/CT has a sensitivity of $95.8 \%$, but both false positive and false negative can occur [17]. 
www.yumedtext.com | September-2021 | ISSN: 2582-5038 | https://dx.doi.org/10.46527/2582-5038.194

\section{Conclusion}

Hürthle cell adenoma is a rare type of benign thyroid lesion that seems to be difficult to diagnose before surgery. Fine needle aspiration cytology may show Hürthle cell lesions but for the confirmation whether it is adenoma or carcinoma, histopathology is needed. Genetic tests may aid in early detection and distinction of adenoma from neoplasia. When nodal involvement is confirmed and the tumor size is larger than $4 \mathrm{~cm}$, total thyroidectomy and lymphadenectomy is the choice of surgical intervention.

\section{REFERENCES}

1. Singh RK, Goyal A, Elhence P, et al. Bilateral Hurthle cell adenoma of thyroid: a rare case report. Int J Otorhinolaryngol Head Neck Surg. 2017;3(2):462.

2. Lloyd RV, Osamura RY, Klöppel G, et al. WHO Classification of Tumours of Endocrine Organs. 4th edn. France: IARC Press; 2017.

3. Gopal RK, Kübler K, Calvo SE, et al. Widespread chromosomal losses and mitochondrial DNA alterations as genetic drivers in Hürthle cell carcinoma. Cancer Cell. 2018;34(2):242-55.

4. Ganly I, Makarov V, Deraje S, et al. Integrated genomic analysis of Hürthle cell cancer reveals oncogenic drivers, recurrent mitochondrial mutations, and unique chromosomal landscapes. Cancer cell. 2018;34(2):256-70.

5. Santana NO, Freitas RM, Marcos VN, et al. Diagnostic performance of thyroid ultrasound in Hürthle cell carcinomas. Arch Endocrinol Metab. 2019;63(3):300-5.

6. Maizlin ZV, Wiseman SM, Vora P, et al. Hürthle cell neoplasms of the thyroid: sonographic appearance and histologic characteristics. J Ultrasound Med. 2008;27(5):751-7.

7. Chen H, Nicol TL, Udelsman R. Follicular lesions of the thyroid. Does frozen section evaluation alter operative management? Ann Surg. 1995;222(1):101.

8. Ito Y, Hirokawa M, Miyauchi A, et al. Diagnosis and surgical indications of oxyphilic follicular tumors in Japan: Surgical specimens and cytology. Endocrine J. 2016;63(11):977-82.

9. Lopez-Penabad L, Chiu AC, Hoff AO, et al. Prognostic factors in patients with Hürthle cell neoplasms of the thyroid. Cancer. 2003;97(5):1186-94.

10. Haugen BR, Sawka AM, Alexander EK, et al. American Thyroid Association guidelines on the management of thyroid nodules and differentiated thyroid cancer task force review and recommendation on the proposed renaming of encapsulated follicular variant papillary thyroid carcinoma without invasion to noninvasive follicular thyroid neoplasm with papillary-like nuclear features. Thyroid. 2017;27(4):481-3.

11. Schatz-Siemers N, Brandler TC, Oweity T, et al. Hürthle cell lesions on thyroid fine needle aspiration cytology: Molecular and histologic correlation. Diagnostic Cytopathol. 2019;47(10):977-85.

12. Norton JA. Problems in general surgery: Surgery of thyroid gland. New York: Lippencott-Raven, USA; 1997.1 -13 p.

13. Donatini G, Beaulieu A, Castagnet M, et al. Thyroid Hürthle cell tumors: research of potential markers of malignancy. J Endocrinol Invest. 2016;39(2):153-8.

14. Stojadinovic A, Hoos A, Ghossein RA, et al. Hürthle cell carcinoma: a 60-year experience. Ann Surg Oncol. 2002;9(2):197-203.

15. Kushchayeva Y, Duh QY, Kebebew E, et al. Prognostic indications for Hürthle cell cancer. World J Surg. 2004;28(12):1266-70. 
www.yumedtext.com | September-2021 | ISSN: 2582-5038 | https://dx.doi.org/10.46527/2582-5038.194

16. Tai P, Korzeniowski M, Sadikov E, et al. Issues in managing Hurthle cell carcinoma of thyroid: a case report. Cureus. 2017;9(4):e1167.

17. Lamartina L, Deandreis D, Durante C, et al. Imaging in the follow-up of differentiated thyroid cancer: current evidence and future perspectives for a risk-adapted approach. Eur J Endocrinol. 2016;175(5):R185-202. 